\title{
Performance of upflow anoxic bioreactor for wastewater treatment
}

\author{
${ }^{1 *}$ S. K. Behera, ${ }^{2}$ E. R. Rene, ${ }^{3}$ D. V. S. Murthy \\ ${ }^{1}$ Department of Civil and Environmental Engineering, University of Ulsan, South Korea \\ ${ }^{2}$ University of La Coruña, Department of Chemical Engineering, Faculty of Sciences, Campus da Zapateira \\ E-15071-La Coruña, Spain \\ ${ }^{3}$ Department of Chemical Engineering, Indian Institute of Technology Madras, Chennai, India \\ Received 13 November 2006; revised 27 February 2007; accepted 9 March 2007; available online 20 March 2007
}

\begin{abstract}
Laboratory scale studies were conducted in an up-flow anoxic bioreactor (UFAB) using synthetic fertilizer wastewater for ascertaining the denitrification efficiency. The performance of the reactor was compared using ethanol and topioca starch as the carbon source. The initial $\mathrm{NO}_{3}-\mathrm{N}$ concentrations $(50-250 \mathrm{mg} / \mathrm{L})$ and hydraulic retention time (HRT, 12-24 h) were varied to evaluate the COD and $\mathrm{NO}_{3}-\mathrm{N}$ removal. The results from this study shows that ethanol gave very good denitrification efficiency (78-98\%) compared to topioca starch (68-96\%).

Key words: Denitrification, topioca wastewater, up-flow anoxic bioreactor, HRT
\end{abstract}

\section{INTRODUCTION}

Nitrogen is one of the principal nutrients of concern in treated wastewater discharges. The increased use of nitrate $\left(\mathrm{NO}_{3}-\mathrm{N}\right)$ fertilizers and discharge of partially treated industrial wastes to rivers leads to exceedingly high $\mathrm{NO}_{3}-\mathrm{N}$ levels in rivers and groundwater. High levels of $\mathrm{NO}_{3}-\mathrm{N}$ are a major contributing factor in the problem of eutrophication of water bodies. The drinking water standard set by the European Economic Community (EEC) for $\mathrm{NO}_{3}-\mathrm{N}$ is $50 \mathrm{mg} / \mathrm{L}$, while $44 \mathrm{mg} / \mathrm{L}$ was set by the U.S. Environmental Protection Agency (USEPA). Nitrogen removal can be effectively accomplished by biological processes involving the nitrification and denitrification steps. Abu-Ghararah, 1996 investigated the influence of type of carbon source and $\mathrm{NO}_{3}-\mathrm{N}$ loading on the denitrification process of $\mathrm{NO}_{3}-\mathrm{N}$ contaminated drinking water in an anoxic static bed column. $\mathrm{NO}_{3}-\mathrm{N}$ loading in the range $0.240-1.30 \mathrm{Kg}$ $\mathrm{NO}_{3}-\mathrm{N} / \mathrm{m}^{3}$.day was investigated. The results of the study have shown that the system should be operated at a maximum $\mathrm{NO}_{3}-\mathrm{N}$ loading of $0.45 \mathrm{Kg} \mathrm{NO}_{3}-\mathrm{N} / \mathrm{m}^{3}$.day to treat waters having a $\mathrm{NO}_{3}-\mathrm{N}$ concentration of 500 $\mathrm{mg} / \mathrm{l}$ to the allowable effluent $\mathrm{NO}_{3}-\mathrm{N}$ and $\mathrm{NO}_{2}-\mathrm{N}$ concentrations. Bilanovic, et al., 1999 studied denitrification under high nitrite concentration in fedbatch mode. Methanol, sodium acetate and effluent from anaerobic digesters were compared as carbon

\footnotetext{
*Corresponding author, Email: shishir_kb@yahoo.com

Tel.: +82-52-259-1447; Fax: +82-52-259-0152
}

sources. A maximum nitrite removal rate was found to be $0.486 \mathrm{~g} \mathrm{NO}_{3}-\mathrm{N} / \mathrm{g}$ VSS.day. Nitrite accumulated initially but its concentration decreased with time and reached zero when acetate or other effluents were used as carbon source. Up-flow anoxic bioreactors (UFAB) are biological systems that have proved to achieve high denitrification rates under controlled operating conditions. The main objective of the present study is to evaluate the COD and $\mathrm{NO}_{3}-\mathrm{N}$ removal efficiency using HRT and influent $\mathrm{NO}_{3}-\mathrm{N}$ concentration as the independent variables.

\section{MATERIALS AND METHODS}

Experimental

The laboratory scale anoxic up-flow bioreactor used in this study is shown in Fig. 1. It was made of acrylic cylinder (100 mm ID*1100 mm height) having 8 lit capacity. Polyurethane foams in the form of $30 \mathrm{~mm}$ cubes were used as packing material which serves as supporting media for the micro-organisms in the reactor. The packed bed height was $64.5 \mathrm{~cm}$. The reactor had perforated plates to hold the packing firmly. The perforations in the plate also ensured uniform distribution of influent wastewater through the reactor bed. The influent synthetic wastewater moved upward through the packed bed with different velocities based on hydraulic retention time (HRT). Along the reactor length, two taps were provided at heights of $23 \mathrm{~cm}$ and 
$44.5 \mathrm{~cm}$ from the base which served as sampling ports. The final effluent was collected after the substrate had moved through the complete packed height of $64.5 \mathrm{~cm}$. The $\mathrm{CO}_{2}$ and $\mathrm{CH}_{4}$ gases were collected through outlet tap in tubes by the downward displacement of water. The substrate was fed into the reactor continuously by a variable speed peristaltic pump.

\section{Media composition}

The synthetic fertilizer wastewater compositions as shown in Tables 1 and 2 were used in this study, Menoud, et al., 1999. Tapioca starch slurry and ethanol were used as carbon sources.

Table 1: Synthetic fertilizer wastewater composition

\begin{tabular}{clc}
\hline Sl.No & Constituent & Composition \\
\hline 1 & Glucose & $1000 \mathrm{mg} / \mathrm{L}$ \\
2 & $\mathrm{NH}_{4} \mathrm{NO}_{3}$ & $80 \mathrm{mg} / \mathrm{L}$ \\
3 & $\mathrm{KH}_{2} \mathrm{PO}_{4}$ & $30 \mathrm{mg} / \mathrm{L}$ \\
4 & $\mathrm{~K}_{2} \mathrm{HPO}_{4}$ & $15 \mathrm{mg} / \mathrm{L}$ \\
5 & Nutrient solution & $1 \mathrm{~mL}$ \\
\hline
\end{tabular}

Table 2: Composition of nutrient solution

\begin{tabular}{clc}
\hline Sl.No & Chemical & Composition (g/L) \\
\hline 1 & $\mathrm{MgSO}_{4} \cdot 7 \mathrm{H}_{2} \mathrm{O}$ & 90 \\
2 & $\mathrm{CaCl}_{2} \cdot 2 \mathrm{H}_{2} \mathrm{O}$ & 6 \\
3 & $\mathrm{FeCl}_{3} \cdot 6 \mathrm{H}_{2} \mathrm{O}$ & 1.5 \\
4 & $\mathrm{MnCl}_{2} \cdot 4 \mathrm{H}_{2} \mathrm{O}$ & 6.5 \\
5 & $\mathrm{ZnSO}_{4} \cdot 7 \mathrm{H}_{2} \mathrm{O}$ & 1.7 \\
6 & $\mathrm{CuCl}_{2} \cdot 2 \mathrm{H}_{2} \mathrm{O}$ & 0.1 \\
7 & $\mathrm{CoCl}_{2} \cdot 6 \mathrm{H}_{2} \mathrm{O}$ & 1.9 \\
8 & $\mathrm{NiSO}_{4} \cdot 6 \mathrm{H}_{2} \mathrm{O}$ & 6.5 \\
9 & $\mathrm{H}_{3} \mathrm{BO}_{3}$ & 0.1 \\
10 & $\mathrm{Na}_{2} \mathrm{MoO}_{4} 2 \mathrm{H}_{2} \mathrm{O}$ & 0.6 \\
11 & $\mathrm{Yeast} \mathrm{extract}$ & 1 \\
\hline
\end{tabular}

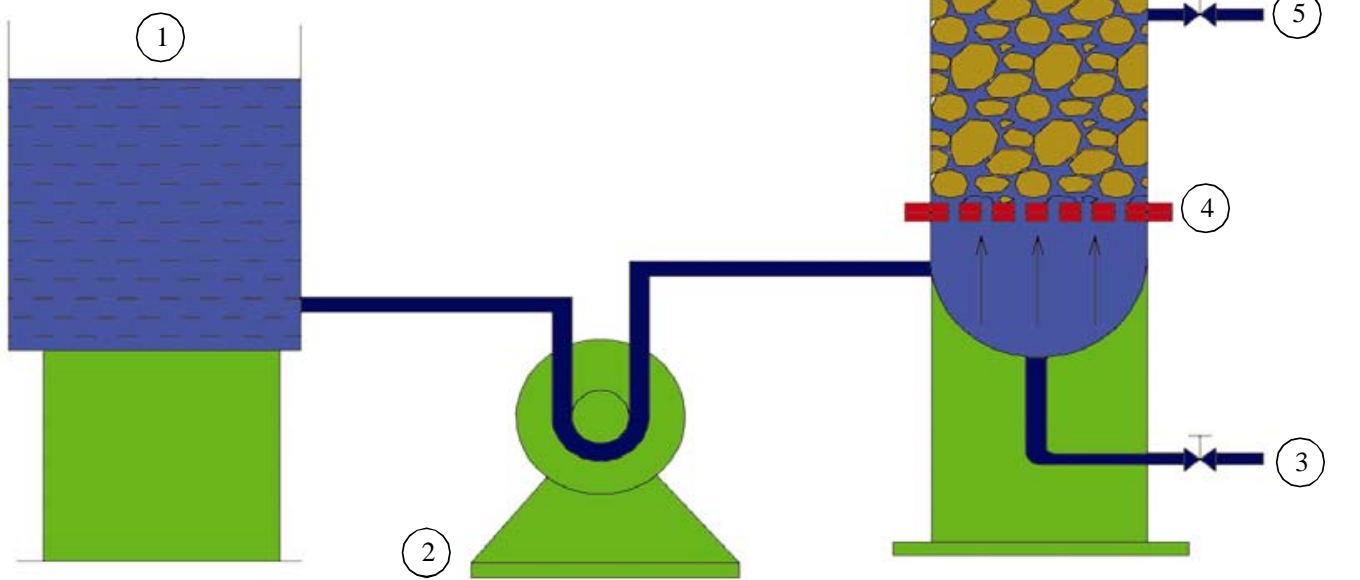

Fig. 1: Schematic of the experimental UFAB (1) Synthetic wastewater; (2) Peristaltic pump; (3) Draining port; (4) Perforated plate; (5) Sampling port; (6) Filter media; (7) Effluent outlet; (8) Liquid

hold-up; (9) Gas collection and measurement
Start up and acclimatization

Cow dung slurry of $8 \mathrm{~L}$ was fed regularly into the reactor with $24 \mathrm{~h}$ HRT for a period of about 4 weeks. Additionally, $500 \mathrm{~mL}$ of a mixture of sludge from a previously operated bioreactor and domestic sewage in equal proportion were also seeded for fast biofilm development. The $\mathrm{pH}$ of the cow dung slurry and sludge mixture was adjusted to 7.5 using sodium bicarbonate. After 4 weeks the cow dung slurry mixture was replaced by synthetic fertilizer wastewater at a rate of $10 \%$ by volume in every $48 \mathrm{~h}$ till the cow dung slurry mixture was reduced to zero volume. The acclimatization step took 33 days for obtaining steady state removal of COD (40\%) and biofilm development.

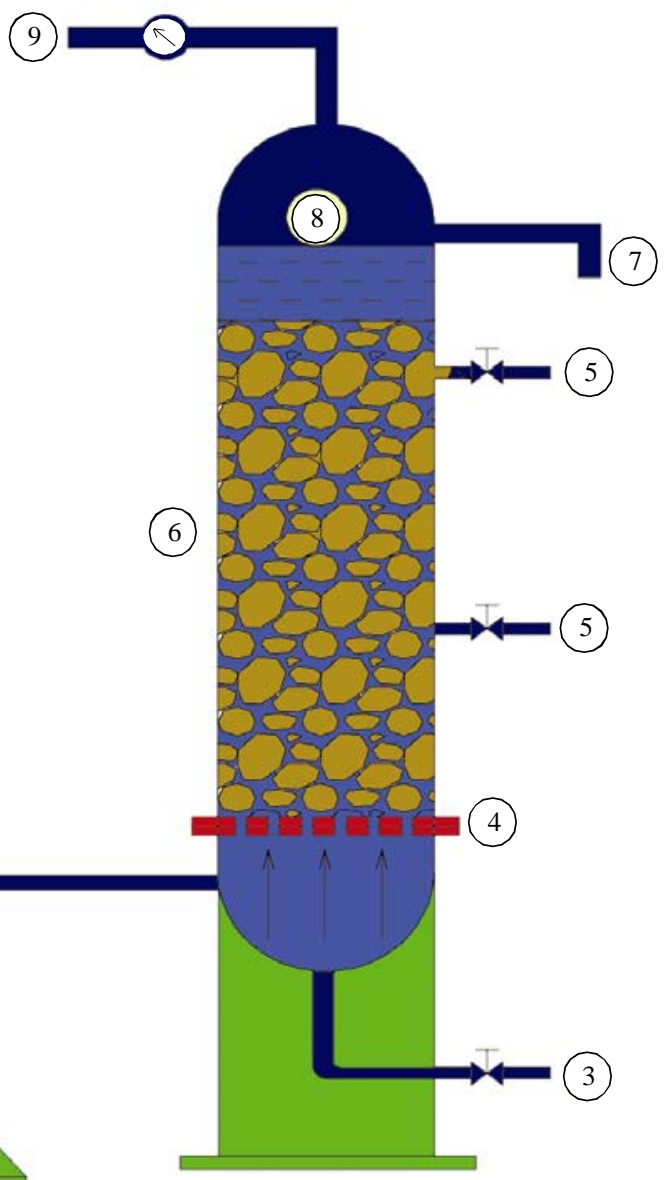


Experimental procedure

The required composition of synthetic fertilizer wastewater was prepared to a volume of $8 \mathrm{~L}$ and passed into the bioreactor at the required flow rate $(0.66,0.44$, $0.33 \mathrm{~L} / \mathrm{h}$ ) with the help of a peristaltic pump. After acclimatization, during continuous experiments the influent $\mathrm{NO}_{3}-\mathrm{N}$ concentration was gradually increased in steps of $50 \mathrm{mg} / \mathrm{L}$. $16 \mathrm{gm}$ of topioca starch powder was added to 8 litres of synthetic fertilizer wastewater. Similarly when carbon source was changed to ethanol, $6.25 \mathrm{~mL}$ of ethanol was added to 8 litres of synthetic fertilizer wastewater. These amounts were taken by determining the COD values of topioca starch and ethanol. The dissolved oxygen values were maintained in the range of 0.6 to $1 \mathrm{mg} / \mathrm{L}$. The HRT was varied between 12-24 h, while the NO3-N concentrations were between 50-250 mg/L depending on the carbon source. $\mathrm{COD}$ and $\mathrm{NO}_{3}-\mathrm{N}$ analysis were performed according to the procedure outlined in Standard Methods (APHA, 1992).

\section{RESULTS}

To understand the denitrification performance in UFAB using two different carbon sources, a synthetic wastewater of a known composition was fed to the bioreactor. During the start-up period the $\mathrm{pH}$ of the influent and effluent was monitored and was found to be fluctuating in a normal way (7-7.8). 33 days of acclimation was considered sufficient for the bioreactor based on the results. During this period, glucose was used as the carbon source. A near steady state was observed in \% COD removal for about five days (Fig. 2) following which regular experiments were performed to monitor the effect of HRT and influent $\mathrm{NO}_{3}-\mathrm{N}$ concentration on $\mathrm{COD}$ and $\mathrm{NO}_{3}-\mathrm{N}$ removal. Fig. 3 shows the percentage $\mathrm{NO}_{3}-\mathrm{N}$ nitrogen and COD removal efficiency variation with influent $\mathrm{NO}_{3}-\mathrm{N}$ concentration when topioca starch was used as carbon source and HRT was 24 hours. As the influent concentration of $\mathrm{NO}_{3}-\mathrm{N}$ nitrogen increases (50 to 150 $\mathrm{mg} / \mathrm{L}$ ) the $\mathrm{NO}_{3}-\mathrm{N}$ nitrogen and COD removal efficiencies decreased.

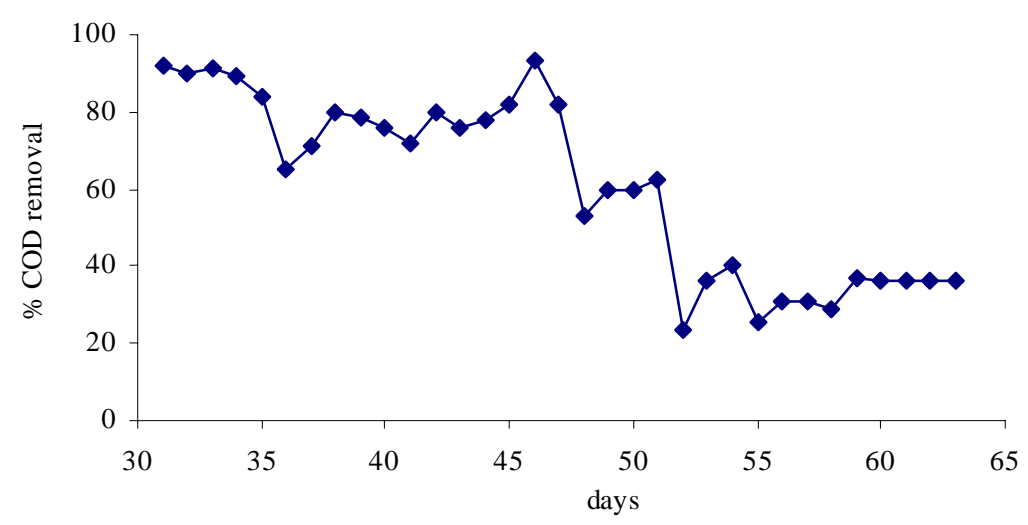

Fig. 2: Start up and acclimatization of anoxic bioreactor

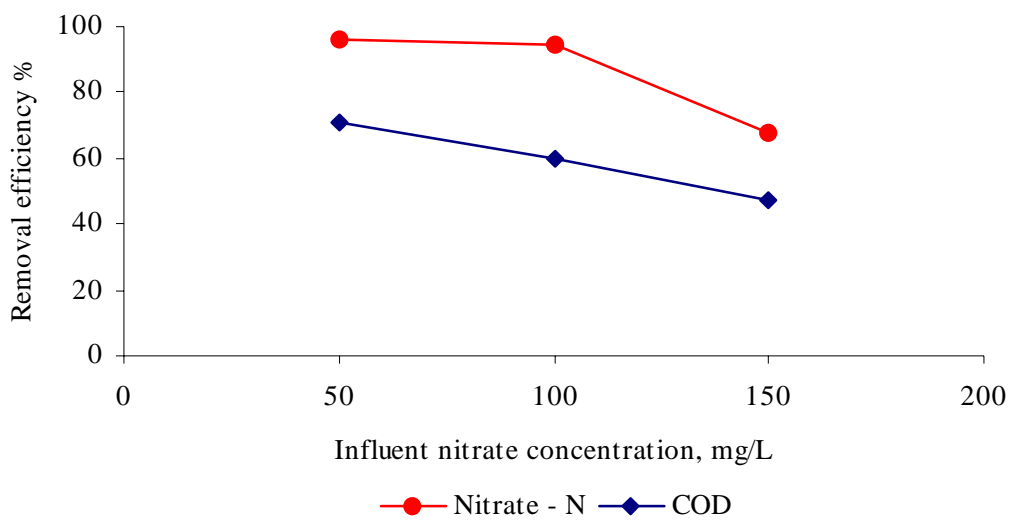

Fig. 3: Effect of Influent $\mathrm{NO}_{3}-\mathrm{N}$ concentration on Removal efficiency (Carbon source: Topioca starch, HRT: $24 \mathrm{~h}$ ) 
Performance of up - flow anoxic bioreactor for wastewater...

Fig. 4 shows the $\mathrm{NO}_{3}-\mathrm{N}$ and COD removal efficiency variation with influent $\mathrm{NO}_{3}-\mathrm{N}$ concentration when ethanol was used as carbon source and HRT was $24 \mathrm{~h}$. As the influent concentration of $\mathrm{NO}_{3}-\mathrm{N}$ nitrogen increases (50 to $250 \mathrm{mg} / \mathrm{L}$ ) the $\mathrm{NO}_{3}-\mathrm{N}$ nitrogen and COD removal efficiency decreased. Rajapakse and Scutt, 1999 investigated the treatment of synthetic wastewater (by dissolving $\mathrm{NaNO}_{3}$ in tap water) using methanol as the carbon source. Their results reveal that, as influent $\mathrm{NO}_{3}-\mathrm{N}$ nitrogen concentration increased, denitrification efficiency decreased. This tendency is similar to the present results of the synthetic fertilizer wastewater investigation carried out.

From these figures, it is evident that ethanol yields better denitrification efficiency compared to tapioca starch. When topioca starch was used as carbon source and influent concentration increased from 100 to 150 $\mathrm{mg} / \mathrm{L}, \mathrm{NO}_{3}-\mathrm{N}$ nitrogen removal efficiency drastically reduced by $26.6 \%$, whereas when ethanol was used as the carbon source $\mathrm{NO}_{3}-\mathrm{N}$ nitrogen removal efficiency is just reduced by $3.35 \%$.In the case of topioca starch as carbon source, it has to undergo hydrolysis as well as acid production stages before it becomes an alcoholic compound. But ethanol being a direct alcohol acts quickly and serves as a ready carbon source. Probably this is the reason for the enhanced efficiency in the case of ethanol as carbon source. The $\mathrm{NO}_{3}-\mathrm{N}$ nitrogen and COD removal efficiency variation with HRT when topioca starch and ethanol were used as carbon source and influent $\mathrm{NO}_{3}-\mathrm{N}$ concentration was $50 \mathrm{mg} / \mathrm{L}$ is shown in Figs. 5 and 6 respectively. It can be seen that the denitrification efficiency and \% COD removal efficiency increased with increase in HRT.

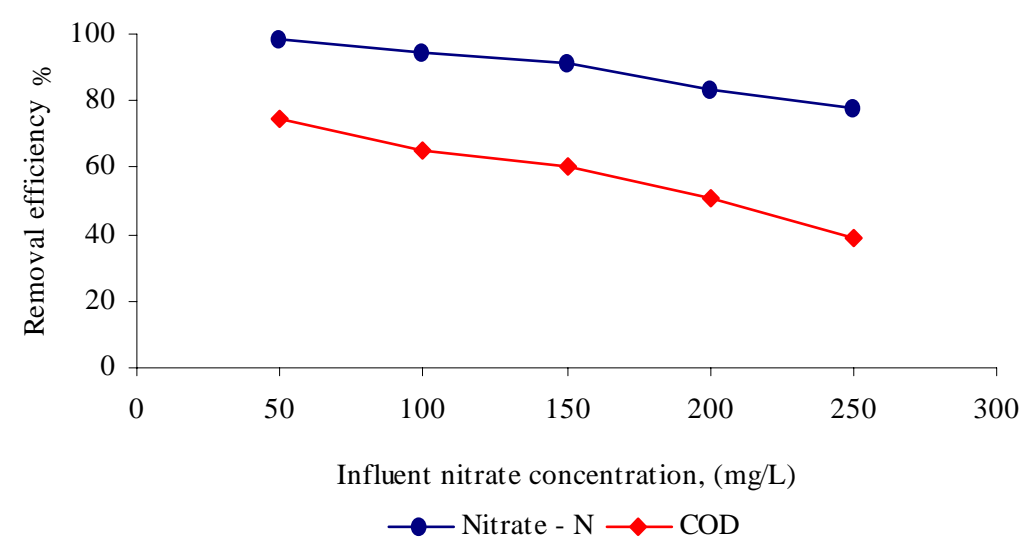

Fig. 4: Effect of influent $\mathrm{NO}_{3}-\mathrm{N}$ concentration on removal efficiency (Carbon source: Ethanol, HRT: 24 h)

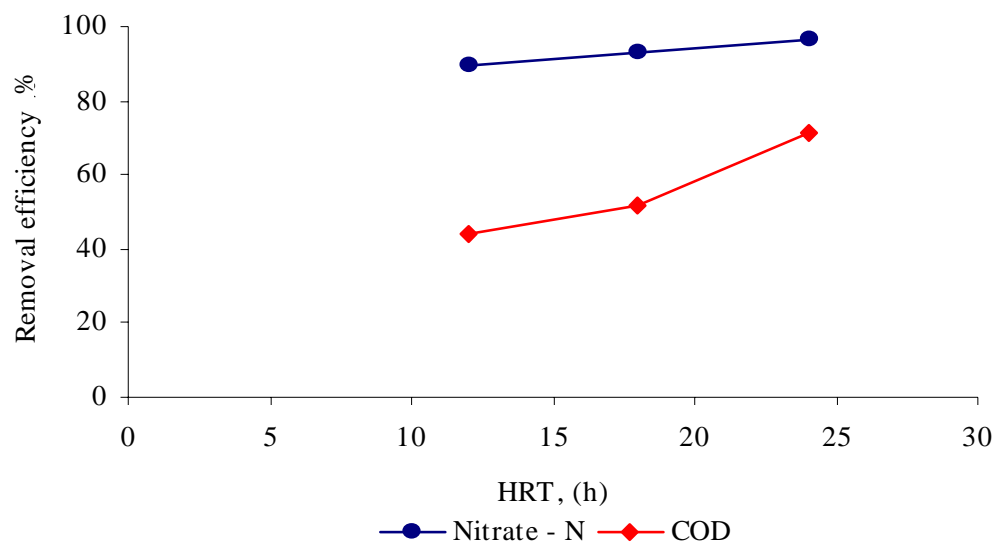

Fig. 5: Effect of HRT on removal efficiency

(Carbon source: Topioca starch, Influent $\mathrm{NO}_{3}-\mathrm{N}$ concentration: $50 \mathrm{mg} / \mathrm{L}$ ) 


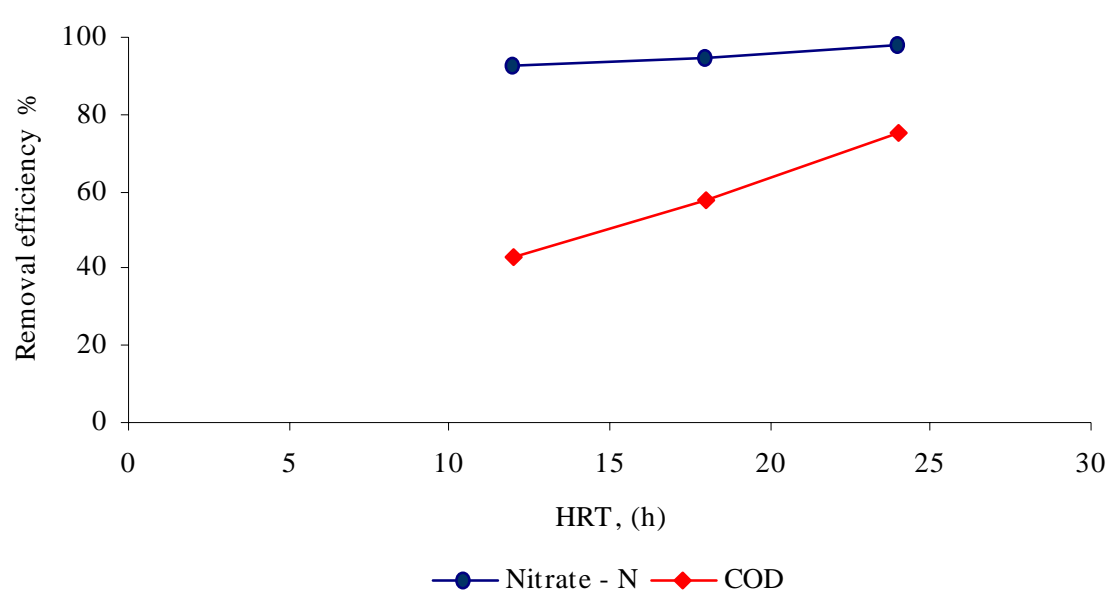

Fig. 6: Effect of HRT on removal efficiency

(Carbon source: Ethanol, Influent $\mathrm{NO}_{3}-\mathrm{N}$ concentration: $50 \mathrm{mg} / \mathrm{L}$ )

\section{DISCUSSION AND CONCLUSION}

An increase in $\mathrm{NO}_{3}-\mathrm{N}$ concentration in the influent ( 50 to $250 \mathrm{mg} / \mathrm{L}$ ) decreases the $\mathrm{NO}_{3}-\mathrm{N}$ removal efficiency in UFAB. When topioca starch was used as the carbon source, denitrification efficiency reduced from 96.4 to $68 \%$ while the denitrification efficiency reduced from 98.2 to $78 \%$ when influent $\mathrm{NO}_{3}-\mathrm{N}$ nitrogen concentration increased from 50 to $250 \mathrm{mg} / \mathrm{L}$ for ethanol. With increase in HRT, denitrification efficiency increases irrespective of type of carbon sources. But at minimum HRT of $12 \mathrm{~h}$ (taken in this study) ethanol yields better denitrification efficiency of $92.4 \%$ compared to topioca starch of $89.5 \%$ at same influent $\mathrm{NO}_{3}-\mathrm{N}$ concentration of $50 \mathrm{mg} / \mathrm{L}$. The results from this study can be applicable for treating topioca and ethanol laden wastewater in field applications.

\section{ACKNOWLEDGEMENTS}

The authors would like to gratefully acknowledge their thanks to IIT Madras for funding this research work.

\section{REFERENCES}

American Public Health Association (APHA), (1992). Standard Methods for the Examination of water and wastewater. $18^{\text {th. }}$ Ed., Newyork.

Abu-Ghararah, Z.H., (1996). Biological denitrification of high nitrate water: Influence of type of carbon source and nitrate loading. J.Environ. Sci. Health., A31 (7), 1651-1668.

Bilanovic, D., Battistoni, P., Cecchi, F., Pavan, P., Alvarezs, J.M., (1999). Denitrification under high nitrate concentration and alternating anoxic conditions. Wat. Res., 33(15), 3311-3320.

Menoud, P., Wong, C.H., Robinson, H.A., Farquhar, Barford, J.P., Barton, G.W., (1999). Simultaneous nitrification and denitrification using Siporax ${ }^{\mathrm{TM}}$ packing. Wat. Sci. Tech., 40 (4-5), 153-160.

Rajapakse, J.P., Scutt, J.E., (1999). Denitrification with natural gas and various new growth media. Wat. Res., 33 (18), 37233734. 


\section{AUTHOR (S) BIOSKETCHES}

Behera, S.K., M.Tech. in Chemical Engineering, IIT Madras, Chennai, India, Ph.D. Scholar at the Civil and Environmental Engineering Department, University of Ulsan, Republic of Korea.

Email: shishir_kb@yahoo.com

Rene, E.R., M.Tech. in Chemical Engineering, NIT Surathkal, Surathkal, India, Ph.D. in Chemical Engineering, IIT Madras, Chennai, India, Post doctoral fellow in Civil and Environmental Engineering Department, University of Ulsan, Republic of Korea, Post doctoral fellow in University of La Coruña, Department of Chemical Engineering, Faculty of Sciences, Campus da Zapateira, E-15071-La Coruña, Spain.

Email: eldonrene@yahoo.com

Murthy D.V.S., Professor Emeritus, Department of Chemical Engineering, IIT Madras, Chennai, India. Email:dvs_murthy@yahoo.com

This article should be referenced as follows:

Behera, S.K., Rene, E.R., Murthy D.V.S., (2007). Performance of up - flow anoxic bioreactor for wastewater treatment. Int. J. Environ. Sci. Tech., 4 (2), 247-252. 